\title{
PENGARUH MOTIVASI DAN KOMPETENSI MELALUI TUGAS BELAJAR TERHADAP KINERJA PEGAWAI NEGERI SIPIL KABUPATEN BARITO SELATAN DI BUNTOK.
}

\author{
Ayi Syarif Hidayat \\ Sekolah Tinggi Ilmu Ekonomi Pancasetia Banjarmasin \\ Jl Ahmad Yani Km. 5.5 Banjarmasin \\ ayisyarifhidayat1981@gmail.com
}

\begin{abstract}
Abstrak: Kinerja Pegawai Negeri Sipil merupakan salah satu faktor penentu baik tidak nya pelayanan di Kabupaten Barito Selatan. Beberapa faktor seperti motivasi dan kompetensi melalui tugas belajar diduga memberikan pengaruh terhadap kualitas kinerja pegawai negeri sipil Kabupaten Barito Selatan di Buntok. Penelitaian ini bertujuan untuk menguji pengaruh motivasi dan kompetensi melalui tugas belajar terhadap kinerja pegawai negeri sipil kabupaten barito selatan di buntok. Objek penelitian adalah Pegawai Negeri Sipil yang sudah selesai menjalani Tugas Belajar maupun Pegawai Negeri Sipil yang sedang menjalani Tugas Belajar dengan pembiayaan melalui APBD Kabupaten Barito Selatan. Penentuan sampel dalam penelitian ini menggunakan simple random sampling, dengan sampel sebanyak 71 responden. Variabel bebas dalam penelitian ini adalah Motivasi dan Kompetensi, dengan Tugas Belajar sebagai variabel interveningnya, sedangkan variabel terikat nya adalah kinerja Pegawai Negeri Sipil. Teknik analisis yang digunakan dalam penelitian ini menggunakan analisis jalur (Path Analysis) dengan bantuan program SPSS. Hasil penelitian menunjukkan bahwa (1) Motivasi memiliki pengaruh secara langsung pada Tugas Belajar seperti yang ditunjukkan oleh nilai betacoefficient standar yang positif sebesar 0,444 dan nilai thitung 4,361, lebih besar dari tabel 1,671. Dengan demikian, hipotesis diterima (2) Kompetensi memiliki pengaruh secara langsung pada Tugas Belajar yang ditunjukkan oleh nilai betacoefficient standar positif sebesar 0,427 dan thitung 4,195, lebih besar dari tabel 1,671. Dengan demikian, hipotesis diterima (3) Motivasi memiliki pengaruh secara langsung pada Kinerja Pegawai Negeri Sipil dengan nilai standar positif yang dibakukan sebesar 0,235 dan $t_{\text {hitung }} 3,391$, lebih besar dari $t_{\text {tabel }}$ 1,671. Dengan demikian, hipotesis diterima. (4) Kompetensi memiliki pengaruh secara langsung terhadap Kinerja Pegawai Negeri Sipil. Hal ini ditunjukkan oleh nilai betacoefficient standar positif sebesar 0,176 dan $t_{\text {hitung }} 2,553$, lebih besar dari pada $t_{\text {tabel }}$ 1,671. Dengan demikian, hipotesis diterima. (5) Tugas Belajar memiliki pengaruh positif secara langsung pada Kinerja Pegawai Negeri Sipil seperti yang ditunjukkan oleh nilai betacoefficient standar positif yang dibakukan antara 0,619 dan $t_{\text {hitung }} 7,913$, lebih besar dari $t_{\text {tabel }}$ 1,671. Dengan demikian, hipotesis diterima.
\end{abstract}

Kata Kunci : Motivasi, Kompetensi, Tugas Belajar, Kinerja Pegawai Negeri Sipil 


\section{LATAR BELAKANG}

Kinerja Pegawai Negeri Sipil atau Aparatur Sipil Negara sangat diharapkan dalam meningkatkan pelayanan publik dimana pegawai negeri sipil merupakan abdi negara sekaligus sebagai abdi masyarakat. Pelayanan publik merupakan hal yang mendesak untuk diperhatikan dan ditingkatkan oleh seluruh aparatur pegawai termasuk pegawai di Kabupaten Barito Selatan karena menyangkut hajat hidup orang banyak, guna mewujudkan kepuasan masyarakat dan kesejahteraan masyarakat yang lebih baik di masa mendatang. Kabupaten Barito Selatan merupakan salah satu instansi pemerintah daerah di Indonesia. Untuk itu manajemen kantor kabupaten yang ada perlu menerapkan kualitas layanan publik yang tinggi, sebagai master plan atau percontohan bagi layanan publik dari berbagai kantor kabupaten lainnya.

Prestasi kerja pegawai yang tinggi dapat dipengaruhi oleh motivasi kerjanya. Dengan motivasi kerja, maka seorang pegawai tidak hanya diperintah untuk dapat bekerja, akan tetapi dengan kesadaran sendiri akan bekerja secara sukarela karena mempunyai dorongan yang kuat untuk berprestasi.

Motivasi pegawai Kabupaten Barito Selatan yang semakin tinggi memungkinkan kualitas layanan dan kinerja pegawai negeri sipil yang semakin tinggi pula. Sebaliknya jika motivasi pegawai rendah, semangat kerja rendah dan gairah untuk meningkatkan kualitas layanan publik semakin berkurang. Untuk itu pemerintah dan pimpinan khususnya pada Kabupaten Barito Selatan perlu memotivasi oleh para pegawai dengan semangat kerja yang tinggi.

Faktor mendasar yang terkait erat dengan kinerja pegawai negeri sipil Kabupaten Barito Selatan adalah motivasi kerja yang berkaitan erat dengan "kesejahteraan" pegawai negeri sipil. Kepuasan pegawai negeri sipil ini dilatarbelakangi oleh faktor-faktor : motivasi kerja, pelatihan yang telah diperoleh sehingga pegawai negeri sipil memiliki kemamapuan kerja yang tinggi. Tampaknya faktor tersebut belum dapat terwujud sepenuhnya dalam lingkungan kehidupan pegawai negeri sipil jika sumber daya manusia yang ada kurang berkualitas.

Salah satu unsur yang ikut mempengaruhi kinerja pegawai negeri sipil adalah kompetensi. Secara asumtif dapat dikatakan bahwa secara tidak langsung terdapat keterkaitan antara kompetensi dan mutu pekerjaan, dalam arti bahwa kompetensi pegawai negeri sipil yang tinggi dapat mempengaruhi mutu pekerjaan. Motivasi kerja pegawai negeri sipil yang masih kurang bahkan saat tenaga mereka dibutuhkan atau pada masa sibuk, dengan seenaknya mereka meninggalkan kewajiban dalam proses pekerjaan, tanpa harus menanggung beban sedikitpun. Beberapa pegawai menganggap meski motivasi kerja mereka tinggi, tetap tidak ada penghargaan, demikian pula jika motivasi kerja rendah, tidak masuk kerja dengan berbagai alasan yang tidak logispun, mereka tidak mendapatkan sanksi apapun, dan tetap mendapatkan gaji yang sama. Oleh karena itu maka motivasi kerja ini perlu mendapatkan perhatian yang baik sehingga motivasi kerja pegawai negeri sipil berasal dari lubuk hatinya yang paling dalam bahwasannya negara dan masyarakat sangat membutuhkan peran aktif pegawai negeri sipil untuk memberikan yang terbaik bagi Kabupaten Barito Selatan agar memberikan layanan publik yang terbaik bagi masyarakat.

Era globalisasi telah menuntut perbaikan layanan publik dimana dalam proses pembangunan sudah saatnya kantor kabupaten yang melayani publik mengedepankan keinginan masyarakat. Hal yang menentukan kesejahteraan masyarakat adalah layanan publik yang berkualitas sehingga masyarakat harus ditempatkan pada posisi penting dalam relasi pemerintah dengan masyarakat, terutama dalam pelayanan publik yang bisa membuat masyarakat sejahtera dan merasa puas dengan layanan publik dari pemerintah daerah khususnya di Kabupaten Barito Selatan. Instansi yang melayani publik harus melibatkan masyarakat dalam Citizen Charter (kontrak pelayanan). Sudah saatnya 
masyarakat dilibatkan dalam posisi demokratis dengan mendengarkan keinginan masyarakat. Jajaran frontline pelayanan yang langsung bersinggungan dengan layanan masyarakat diharapkan mampu memberikan pelayanan yang lebih baik pada masyarakat.

Pembangunan yang dilaksanakan oleh seluruh bangsa Indonesia pada hakekatnya diarahkan pada upaya peningkatan kualitas sumber daya manusia, untuk mewujudkan bangsa yang maju, mandiri, sejahtera lahir dan batin sebagai landasan bagi tahapan pembangunan berikutnya, yaitu masyarakat yang adil dan makmur. Pembangunan adalah proses perubahan ke arah kualitas hidup yang baik, bukan semata-mata ditunjukkan pada perbaikan ekonomi yang diukur dari produksi dan pertumbuhan rata-rata penduduk, akan tetapi juga menghasilkan perubahan pada pola pikir dan kemampuan masyarakat untuk menentukan masa depan sendiri. Demikian pula pelayanan masyarakat perlu diarahkan pada kualitas pelayanan publik yang tinggi sehingga menghasilkan masyarakat yang maju dan sejahtera.

Fenomena perubahan masyarakat tersebut sudah selayaknya dijadikan sebagai titik tolak bagi pihak Kabupaten Barito Selatan untuk mengintrospeksi diri dan dijadikan sebagai wacana untuk mereposisi visi dan misi pelayanan kepada masyarakat, dengan secara terus menerus meningkatkan kualitas pelayanan publiknya agar dapat memenuhi permintaan dan harapan masyarakat. Salah satu upaya dalam meningkatkan kualitas pelayanan masyarakat adalah dengan meningkatkan kualitas kinerja sumber daya manusianya, terutama kompetensi Pegawai Kabupaten Barito Selatan, disamping sumber-sumber daya yang lain.

Permasalahan yang ada menunjukkan bahwa Pegawai Kabupaten Barito Selatan utamanya unsur pimpinan dan pelayanan khususnya pada era reformasi yang sedang dan akan terus berlangsung serta dengan situasi dan kondisi yang penuh gejolak dan ketidakpastian saat ini, menunjukkan kurang optimalnya pelayanan pada masyarakat dan dalam membuat kebijakan penyelenggaraan layanan Kabupaten Barito Selatan, sehingga sering terjadinya berbagai tuntutan masyarakat terhadap kualitas layanan publik Kabupaten Barito Selatan beserta alat kelengkapannya dalam membuat kebijakan penyelenggaraaan Kabupaten Barito Selatan dan pelayanan masyarakat.

Salah satu tugas manajemen sumber daya manusia yaitu mengupayakan agar kinerja pegawai dapat terus meningkat dan terus menjadi lebih baik sesuai dengan kebutuhan organisasi. Oleh karena itu kompetensi pegawai menjadi aspek penting untuk dibahas dalam hal peningkatan kinerja pegawai.

Peningkatan kompetensi sangat penting dilakukan untuk mendukung kemampuan kerja pegawai sekaligus meningkatkan kinerja pegawai, artinya semakin tinggi kompetensi seorang pegawai maka kinerja pegawai tersebut juga akan semakin tinggi. Kompetensi merupakan salah satu faktor yang membedakan seseorang pegawai yang mampu menunjukkan kinerja optimal dengan seseorang pegawai yang tidak mampu menunjukkan kinerja optimal.

Pegawai yang kompeten memiliki pengetahuan dan keterampilan yang baik sehingga mereka bisa memanfaatkan potensipotensi yang mereka miliki dan mampu memahami apa yang harus dikerjakan, serta bagaimana cara mengerjakannya. Namun kompetensi tersebut menjadi tidak berguna apabila pegawai tersebut tidak mampu menterjemahkan kompetensi yang dimilikinya ke dalam perilaku kerja yang efektif.

Indikasi awal kurangnya kompetensi pegawai dilihat dari kurang profesional dalam menjalankan aktivitas kerja, kurang cepat dalam memecahkan masalah, inefisiensi dalam penyelesaian tugas kerja, kurang mampu beradaptasi dengan cepat apabila ada perubahan-perubahan tugas kerja dari atasan, kurang peka menghadapi perkembangan ilmu pengetahuan dan teknologi, serta belum memahami standar pekerjaan yang baik.

Dengan mengevaluasi kompetensi yang dimiliki seorang pegawai, maka pemerintah daerah Kabupaten Barito Selatan 
telah mengambil kebijakan sampai sekarang sudah berjalan untuk meningkatkan kompetensi dan kinerja pegawai yang masih aktif dan memenuhi persyaratan untuk tugas belajar ke luar daerah terutama ke perguruan tinggi di pulau Jawa, yang akan dapat memprediksi kinerja pegawai meningkat. Penentuan kompetensi yang dibutuhkan tentunya akan dapat dijadikan sebagai dasar bagi mengevaluasi kinerja pegawai. Dengan demikian untuk mewujudkan keberhasilan program kerja yang telah ditetapkan pemerintah daerah Kabupaten Barito Selatan, setiap pegawai di dalamnya diharuskan memiliki standar kompetensi yang diharapkan. Kompetensi merupakan faktor kunci penentu bagi seorang pegawai dalam menghasilkan kinerja yang baik. Dalam situasi kolektif, faktor kompetensi juga merupakan faktor kunci penentu keberhasilan suatu organisasi.

Guna menunjang kompetensi dari para pegawai negeri sipil Kabupaten Barito Selatan di Buntok maka telah dilaksanakan tugas belajar bagi para pegawai negeri sipil. Sebagai konsekuensi dari tugas belajar maka membutuhkan waktu dan anggaran bagi Kabupaten Barito Selatan dengan anggaran yang tidak sedikit jumlahnya. Namun walhasil hasil dari tugas belajar dan anggaran yang telah dikeluarkan tidak sedikit kurang memenuhi sasaran karena kinerja para pegawai negeri sipil Kabupaten Barito Selatan di Buntok masih sama dengan tanpa adanya tugas belajar. Untuk itu perlu dievaluasi kembali anggaran dan pemberian tugas belajar, apakah masih perlu dilaksanakan, dikurangi atau dihapuskan saja.

Bertitik tolak dari kondisi yang diuraikan tersebut diatas, maka peneliti mengambil judul : Pengaruh Motivasi dan Kompetensi Melalui Tugas Belajar terhadap Kinerja Pegawai Negeri Sipil Kabupaten Barito Selatan di Buntok.

\section{STUDI LITERATUR}

Manajemen menurut James A.F. Stonner : "Manajemen adalah proses perencanaan, pengorganisasian, pengarahan dan pengawasan usaha-usaha para pegawai negeri sipil organisasi dan penggunaan sumber-sumber daya organisasi lainnya agar mencapai tujuan organisasi yang ditetapkan".

Fungsi manajemen menurut George R.Terry adalah : Perencanaan (Planning), Pengorganisasian

Penggerakan (Actuating), Pengawasan (Controlling).

Istilah manajemen memiliki berbagai pengertian. Secara universal manajemen adalah penggunaan sumberdaya organisasi untuk mencapai sasaran dan kinerja yang tinggi dalam berbagai tipe organisasi, profit maupun non profit. Kata manajemen berasal dari bahasa Italia (1561) maneggiare yang berarti "mengendalikan," terutamanya "mengendalikan kuda" yang berasal dari bahasa latin manus yang berati "tangan". Kata ini mendapat pengaruh dari bahasa Perancis manège yang berarti "kepemilikan kuda" (yang berasal dari Bahasa Inggris yang berarti seni mengendalikan kuda), dimana istilah Inggris ini juga berasal dari bahasa Italia. Bahasa Prancis lalu mengadopsi kata ini dari bahasa Inggris menjadi ménagement, yang memiliki arti seni melaksanakan dan mengatur (Wikipedia, 2020). Pengertian Manajemen menurut Mary Parker Foller (2007), Mangement is the art of getting things done through people, managemen adalah seni menyelesaikan sesuatu melalui orang lain. Menyelesaikan sesuati disini adalah segala sesuatu yang perlu dilakukan dalam rangka menvapai tujuan tertentu. Menurut Nickles, McHingh, dan McHugh (2007) management is the process used the accompalish organizational golas through planning, organizing, directing, and controlling people and other organizational resources. Managemen adalah sebuah proses yang dilakukan untuk mewujudkan tujuan organisasi melalui rangkaian kegiatan berupa perencanaan, pengorganisasian, pengarahan, dan pengendalian orang-orang serta sumber daya organisasi lainnya.

Manajemen Sumber Daya Manusia didefinisikan sebagai suatu perencanaan pengorganisasian, pelaksanaan, dan pengawasan terhadap pengadaan, pengembangan, pemberian balas jasa, pengintegrasian, pemeliharaan, dan 
pemisahan tenaga kerja dalam rangka mencapai tujuan organisasi (Anwar Prabu Mangkunegara, 2001:2) Manajemen sumber daya manusia adalah penarikan, seleksi, pengembangan, pemeliharaan, dan penggunaan sumber daya manusia untuk mencapai titik tujuan-tujuan individu maupun organisasi (Handoko, 2008:4) Manajemen sumber daya manusia merupakan suatu perencanaan, pengorganisasian, pengkoordinasian, pelaksanaan dan pengawasan terhadap pengadaan, pengembangan, pemberian balas jasa, pengintegrasian, pemeliharaan dan pemisahan tenaga kerja dalam rangka mencapai tujuan organisasi (Mangkunegara, 2002:2) Manajemen sumber daya manusia adalah ilmu dan seni mengatur hubungan dan peranan tenaga kerja agar efektif dan efisien membantu terwujudnya tujuan perusahaan, pegawai dan masyarakat (Hasibuan, 2002:10). Pengertian manajemen sumber daya manusia yakni ilmu dan seni mengatur hubungan dan peranan tenaga kerja agar efektif dan efisien membantu terwujudnya tujuan perusahaan, pegawai, dan masyarakat (Hasibuan, 2006:10). Manajemen sumber daya manusia merupakan salah satu bidang dari manajemen umum yang meliputi segisegi perencanaan, pengorganisasian, pelaksana dan pengendalian (Rivai, 2005:1). Manajemen sumber daya manusia didefinisikan sebagai suatu strategi dalam menerapkan fungsi-fungsi manajemen yaitu planning, organizing, leading and controlling, dalam setiap aktifitas atau fungsi operasional sumber daya manusia mulai dari proses penarikan, seleksi, pelatihan dan pengembangan, penempatan yang meliputi promosi, demosi dan transfer, penilaian kinerja, pemberian kompensasi, hubungan industrial, hingga pemutusan hubungan kerja, yang ditujukan bagi peningkatan kontribusi produktif dari sumberdaya manusia organisasi terhadap pencapaian tujuan organisasi secara lebih efektif dan efisien (Sofyandi, 2009:6).Ilmu yang mempelajari bagaimana memberdayakan pegawai dalam perusahaan, membuat pekerjaan, kelompok kerja, mengembangkan para pegawai yang mempunyai kemampuan, mengidentifikasi suatu pendekatan untuk dapat mengembangkan Kinerja pegawai negeri sipil dan memberikan imbalan kepada mereka atas usahanya dan bekerja (Bohlarander dan Snell, 2010:4)

Dari definisi atau pengertian manajemen sumber daya manusia menurut para ahli di atas, maka dapat disimpulkan bahwa manajemen sumber daya manusia merupakan bagian dari manajemen keorganisasian yang menekankan pada unsur SDM dan sudah menjadi tugas manajemen sumber daya manusia untuk mengelola unsur manusia secara baik agar diperoleh tenaga kerja yang tepat sesuai pekerjaannya, sehingga mampu bekerja optimal demi tercapainya tujuan perusahaan atau organisasi. Manajemen SDM merupakan pengelolaan sumber daya manusia dengan mengimplementasikan fungsi manajemen dalam aktivitas operasional demi terwujudnya tujuan organisasi.

Motivasi berasal dari kata latin movere yang berarti dorongan, daya penggerak atau kekuatan yang menyebabkan suatu tindakan atau perbuatan. Kata movere, dalam bahasa Inggris sering disamakan dengan motivation yang berarti pemberian motif atau hal yang menimbulkan dorongan. Pengertian dari motivasi kerja menurut Stephen P. Robbins dan Mary Counter, menyatakan bahwa; "Motivation is the willingness to expend high levels of effort for the purpose of the organization, which is conditioned by the ability of an effort to meet individual needs. In line with this opinion (motivasi adalah kesediaan untuk mengeluarkan tingkat upaya yang tinggi untuk tujuan organisasi, yang dikondisikan oleh kemampuan upaya untuk memenuhi suatu kebutuhan individu. Senada dengan pendapat tersebut)." William McDougall, menyatakan bahwa; "An action that was taken from birth that determines an organism to know or pay attention to any object ..... and the act or acts which have a decisive impulsa ekspersi behave in a specific way, (Suatu tindakan yang dibawa dari lahir yang menentukan organisme untuk mengetahui atau memperhatikan setiap obyek ..... dan bertindak atau mempunyai suatu impulsa 
bertindak yang menentukan ekspersi dalam suatu cara berprilaku yang spesifik)." George R. dan Leslie W. Mengatakan bahwa motivasi adalah "......getting a person to exert a high degree of effort, (motivasi membuat seseorang bekerja lebih berprestasi). Hamzah B. Uno (2012:71) yang menyatakan; "Motivasi Kerja merupakan salah satu faktor yang turut menentukan kinerja seseorang, besar kecilnya pengaruh motivasi kerja pada kinerja seseorang tergantung pada seberapa banyak intensitas motivasi yang diberikan." Dengan demikian dapat dikatakan bahwa motivasi pada dasarnya adalah kondisi mental yang mendorong dilakukannya suatu tindakan (action atau activities) dan memberikan kekuatan yang mengarah kepada pencapaian kebutuhan, memberi kepuasan ataupun mengurangi ketidak seimbangan.

Kompetensi merupakan kekuatan sumber daya manusia yang secara dinamis menunjukkan kapasitas intelektual, kualitas sikap mental dan kapabilitas seseorang. Kompetensi modal awal yang harus dimiliki seorang pegawai untuk dapat melaksanakan pekerjaan sesuai dengan tugas dan tanggung jawabnya. Membahas kompetensi sumber daya manusia berarti membahas karakteristik sumber daya manusia dalam hal ini pegawai yang berkualitas yang dapat menyokong operasional kerja dan pertumbuhan organisasi. Perkembangan kompetensi yang semakin luas dari sumber daya manusia memastikan bahwa manajemen sumber daya manusia memegang peranan penting dalam kesuksesan organisasi. Persepsi tentang pemahaman kompetensi, terdapat perbedaan antara pendekatan Amerika Serikat dengan pendekatan Inggris. Pendekatan Amerika cenderung memandang kompetensi dari "Perspektif perilaku" dimana karakteristik perilaku tersebut dapat menyebabkan kinerja unggul dalam pekerjaannya. Kompetensi dalam perspektif atau pendekatan Amerika Serikat menggunakan terminologi "Competencies". Definisi Amerika merujuk pada keterampilan atau perilaku yang diperlukan untuk mencapai hasil yang diinginkan sedangkan pengertian kompetensi dalam pendekatan Inggris merujuk pada pengakuan aktivitas dalam bentuk hasil kerja atau sebagai kemampuan memenuhi syarat efektif. Pendekatan Inggris memakai penyebutan "Competence". Pada konteks manajemen SDM, kompetensi mengacu kepada atribut atau karakteristik seorang pegawai yang membuatnya berhasil dalam melaksanakan pekerjaan. Menurut Scale dalam Sutrisno (2011:202), secara harfiah kompetensi berasal dari kata competence yang artinya kecakapan, kemampuan dan wewenang. Secara etimologi, kompetensi diartikan sebagai dimensi perilaku keahlian atau keunggulan seorang pemimpin atau staf yang mempunyai keterampilan, pengetahuan dan perilaku yang baik. Menurut Lyle Spencer dan Signe Spencer dalam Moeheriono (2012:5), kompetensi adalah karakteristik yang mendasari seseorang berkaitan dengan efektivitas kinerja individu dalam pekerjaannya atau karakteristik individu yang memiliki hubungan kausal atau sebagai sebab akibat dengan kriteria yang dijadikan acuan, efektif atau berkinerja prima superior ditempat kerja pada situasi tertentu. Menurut Mclelland dalam Sedarmayanti (2012:283), kompetensi adalah karakteristik yang mendasar yang dimiliki seseorang yang berpengaruh langsung terhadap atau dapat memprediksikan kinerja yang sangat baik. Menurut Wibowo (2010:324), kompetensi adalah suatu kemampuan untuk melaksanakan atau melakukan suatu pekerjaan atau tugas yang dilandasi atas keterampilan dan pengetahuan serta didukung oleh sikap kerja yang dituntut oleh pekerjaan tersebut. Menurut Wirawan (2009:9), kompetensi sebagai karakteristik pengetahuan, keterampilan, perilaku, dan pengalaman untuk melakukan suatu pekerjaan atau peran tertentu secara efektif. Menurut Agency dalam Sudarmanto (2009:48), mengemukakan kompetensi sebagai kemampuan untuk menjalankan aktivitas dalam pekerjaan atau fungsi sesuai dengan standar kerja yang diharapkan. Menurut Fletcher dalam Ramelan (2005:2), kompetensi adalah hasil standar dari pekerjaan atau perilaku standar dalam peran pekerjaan tertentu. Menurut Simamora (2004:92), kompetensi adalah jenis keahlian, 
pengetahuan, dan kemampuan yang diperlukan untuk menunaikan sebuah pekerjaan secara efektif. Menurut Prihadi (2004:91), mendefinisikan kompetensi merupakan seperangkat pengetahuan, keterampilan dan sikap yang saling terkait yang mempengaruhi jabatan yang diduduki seseorang (peran dan tanggung jawab), berkorelasi dengan kinerja pada jabatan tersebut, dan dapat diukur dengan standarstandar yang diterima serta dapat ditingkatkan melalui pelatihan dan pengembangan. Menurut Noe (2002:94), kompetensi merupakan aspek kemampuan seseorang yang meliputi pengetahuan, keterampilan, sikap, nilai, atau karakteristik pribadi yang memungkinkan pekerja mencapai keberhasilan dalam menyelesaikan tugas-tugas. Kompetensi merupakan variabel utama yang harus dimiliki oleh seorang pegawai dalam melaksanakan pekerjaannya, sehingga dengan adanya kompetensi yang telah dimiliki dapat membantu para pegawai di dalam menyelesaikan pekerjaan sesuai dengan target yang telah ditentukan organisasi.

Kompetensi dikatakan sebagai salah satu faktor yang mempengaruhi kinerja seorang pegawai. Semakin tinggi kompetensi yang dimiliki seorang pegawai maka kinerja pegawai akan meningkat. Kinerja seorang pegawai dapat dilihat dari kompetensi yang dimilikinya, oleh karena itu diharapkan pegawai memiliki kompetensi yang berhubungan dengan tugas dan tanggung jawab pekerjaannya sehingga dapat menghasilkan kinerja yang maksimal di tempat tugasnya. Faktor kompetensi pegawai yang meliputi kesesuaian pengetahuan dan keterampilan dalam pelaksanaan tugas akan memberikan dampak pada kinerja pegawai sebagai perwujudan prestasinya. Semakin tinggi kesesuaian kompetensi seseorang dalam bidang tugasnya akan semakin tinggi tingkat kinerja pegawai.

Pegawai yang kompeten biasanya memiliki karakter sikap, dan kemampuan kerja yang relatif stabil ketika menghadapi situasi di tempat kerja yang terbentuk dari sinergi antara watak, konsep diri, motivasi internal, dan kapasitas pengetahuan kontekstualnya sehingga ia dengan cepat dapat mengatasi permasalahan kerja yang dihadapi, melakukan pekerjaan dengan tenang dan percaya diri serta terbuka meningkatkan kualitas diri. Menurut Mclelland dalam Sedarmayanti (2012:283), kompetensi adalah karakteristik yang mendasar yang dimiliki seseorang yang berpengaruh langsung terhadap atau dapat memprediksikan kinerja yang sangat baik. Menurut Wibowo (2012:323), banyaknya kompetensi yang digunakan oleh sumber daya manusia akan meningkatkan kinerja. Menurut Spencer dalam Moeheriono (2012:8), menyatakan bahwa kompetensi mempunyai hubungan sebab akibat (causality related) jika dikaitkan dengan kinerja seorang pegawai, serta kompetensi yang terdiri atas: motif (motive), sifat (trait), konsep diri (self concept), keterampilan (skill), dan pengetahuan (knowledge) yang dapat memprediksikan perilaku seseorang, sehingga pada akhirnya dapat memprediksi kinerja orang tersebut.

Kemudian Moeheriono (2012:13), menjelaskan kompetensi seseorang termasuk dalam kategori tinggi atau baik nantinya akan dibuktikan dan ditunjukkan apabila ia sudah melakukan pekerjaan. Sebaliknya, apabila mempunyai kompetensi tingkat rendah, ia akan cenderung berkinerja rendah pula. Menurut lyle Spencer dan signe Spencer (2008:78), kompetensi intelektual, emosional, dan sosial sebagai bagian dari kepribadian yang paling dalam pada seseorang yang dapat memprediksi atau mempengaruhi keefektifan kinerja individu. Semakin tinggi kompetensi pegawai maka sudah seharusnya semakin tinggi kinerjanya. Sebaliknya semakin pegawai tidak kompeten maka semakin rendah kinerjanya. Kompetensi dan kinerja yang tinggi memberikan isyarat bahwa suatu organisasi dikelola dengan baik dan secara fundamental akan menghasilkan perilaku manajemen yang efektif. Inti utama sistem kompetensi adalah sebagai alat penentu untuk memprediksikan keberhasilan kerja seorang pegawai. Pendekatan kompetensi dapat dijadikan patokan untuk menilai proses kerja seorang pegawai. 
Tugas Belajar adalah penugasan yang diberikan oleh pejabat yang berwenang kepada PNS untuk melanjutkan pendidikan ke jenjang yang lebih tinggi atau yang setara baik di dalam maupun di luar negeri, bukan atas biaya sendiri, dan meninggalkan tugas sehari-hari sebagai PNS. Distingsi atau perbedaan tugas belajar dan ijin belajar kepada Pegawai Negeri Sipil (PNS) harus dicermati dengan baik. Pemahaman ini perlu dimiliki oleh Pejabat Pembina Kepegawaian (PPK) dan pegawai yang hendak meneruskan studinya. Ada pun Ijin belajar adalah ijin mengikuti pendidikan bagi PNS tanpa meninggalkan tugas dan biaya pendidikannya ditanggung sendiri oleh pegawai yang bersangkutan (www.bkn.go.id. 2020). Apabila pegawai yang bersangkutan telah lulus dan memperoleh ijazah, tidak dengan sendirinya yang bersangkutan dapat diusulkan kenaikan pangkat berdasarkan penyesuaian ijazah. Kenaikan pangkat penyesuaian ijazah bukan hak, oleh karena itu hanya dapat diberikan apabila sejalan dengan kebutuhan organisasi / formasi yang ada. Dasar hukum pelaksanaan tugas belajar antara lain:

1. Surat Edaran Menteri Pendayagunaan Aparatur Negara dan Reformasi Birokrasi Nomor 04 Tahun 2013 tentang Pemberian Tugas Belajar dan Ijin Belajar

2. Pasal 70 UU Nomor 5 Tahun 2014 tentang ASN

3. PP Nomor 11 Tahun 2017 tentang Manajemen PNS

Kinerja menurut Stolovitch and Keeps (2002: 5) adalah "Merupakan seperangkat hasil yang dicapai dan merujuk pada tindakan pencapaian serta pelaksanaan sesuatu pekerjaan yang diminta." Robbin (2006: 131) Tiga kriteria penilaian kinerja individu antara lain tugas individu, perilaku individu dan ciri individu. Casio (2002: 34) " Kinerja merujuk pada pencapaian tujuan pegawai atas tugas yang diberikan." Dari tiga pengertian tersebut dapat disimpulkan penilaian kinerja merupakan kumpulan total dari kerja yang merupakan tugas dan ciri individu guna mencapai sasaran / target yang ditentukan pimpinan. Rivai (2004: 99 ) mendefinisikan manfaat penilaian kinerja sesuai dengan pihak-pihak yang berkepentingan dengan penilaian meliputi :

a. Manfaat bagi pegawai yang dinilai, meningkatkan motivasi, kepuasan kerja, hasil yang diharapkan, pengetahuan.

b. Manfaat bagi penilai, kesempatan mengidentifikasi pegawai, memberikan peluang serta meningkatkan kepuasan kerja bagi keduanya.

c. Manfaat bagi organisasi, perbaikan seluruh simpul unit dalam organisasi, meningkatkan kualitas komunikasi serta motivasi dan kehannonisan antara pegawai dan organisasi.

Dalam Peraturan Pemerintah No.10 tahun 2009 tentang Penilaian pelaksanaan pekerjaan Pegawai Negeri Sipil (PNS) menyebutkan bahwa untuk memperoleh bahan pertimbangan yang obyektif dan pembinaan PNS diperlukan Daftar Penilaian Pelaksanaan Pekerjaan (DP3) yang unsurnya meliputi : 1 . Kesetiaan, 2. Prestasi Kerja, 3. Tanggung Jawab, 4. Ketaatan, 5. Kejujuran, 6. Kerjasama. 7. Prakarsa, 8 Kepemimpinan.

Unsur-unsur yang dinilai untuk tenaga pelaksana adalah poin 1 sampai dengan 6 , sedangkan penilaian untuk tingkat manager adalah seluruh unsur seperti tersebut diatas. Kinerja pegawai pada dasarnya adalah hasil kerja seorang pegawai selama periode tertentu dibandingkan dengan berbagai kemungkinan misalnya standar, target/sasaran atau kriteria yang telah ditentukan terlebih dahulu dan telah disepakati bersama (Soeprihanto, 2008: 7). Sedangkan penulis lain (Byars dan Rue, 2004: 310) menyatakan bahwa Kinerja pegawai adalah menunjukkan derajat penyelesaian tugas yang menyertai pekerjaan seorang individu. Kinerja adalah merefleksikan seberapa baik seorang individu memenuhi permintaan-permintaan sebuah pekerjaan.

Penelitian terdahulu yang menjadi fondasi dari penelitian yang dilakukan diantaranya adalah :

1. Muhammad Dicky Afifi. Mochammad Al Musadieq dan Gunawan Eko Nurtjahjono. Jurnal Administrasi Bisnis (JAB). Vol. 29 No. 1 Desember 2015. Pengaruh 
Kemampuan Kerja Dan Motivasi Kerja Terhadap Prestasi Kerja (Studi pada Karyawan PR. Sejahtera Abadi Malang). Penelitian dengan judul "Pengaruh Kemampuan Kerja dan Motivasi Kerja Terhadap Prestasi Kerja" yang dilakukan kepada karyawan PR.Sejahtera Abadi Malang ini bertujuan untuk menjelaskan pengaruh variabel Kemampuan Kerja Karyawan dan Motivasi Kerja Karyawan secara simultan dan parsial terhadap Prestasi Kerja Karyawan. Metode penelitian yang digunakan adalah metode explanatory research, dengan menggunakan kuesioner sebagai alat pengumpul data yang disebarkan kepada 71 karyawan di PR.Sejahtera Abadi Malang. Analisa data dalam penelitian ini menggunakan analisis deskriptif dan analisis regresi linier berganda yang dibantu dengan komputer program SPSS for Windows. Hasil analisis regresi linier berganda menunjukkan bahwa secara simultan dan parsial variabel Kemampuan Kerja Karyawan dan Motivasi Kerja Karyawan mempunyai pengaruh yang signifikan terhadap Prestasi Kerja Karyawan. Hal ini ditunjukkan dengan hasil Uji simultan diperoleh nilai signifikansi $F$ sebesar 0,000 yang lebih kecil dari $\alpha$ sebesar $0,05(0,000<0,005)$. Untuk mengetahui pengaruh parsial variabel bebas Kemampuan KerjaKaryawan (X1) berpengaruh terhadap Prestasi Kerja Karyawan (Y) dilakukan dengan pengujian uji $t$. Berdasarkan pada hasil uji didapatkan bahwa variabel bebas Kemampuan Kerja Karyawan (X1) mempunyai pengaruh signifikan terhadap Prestasi Kerja Karyawan (Y).

2. Zainal. Pengaruh Kemampuan Kerja, Pengalaman Kerja Dan Disiplin Kerja Terhadap Kinerja Pegawai Negeri Sipil (PNS) Pada Kantor Kecamatan Bahodopi
Kabupaten Morowali. Tujuan dari penelitian ini adalah: 1) untuk mengetahui dan menganalisis pengaruh kemampuan kerja, pengalaman kerja, dan disiplin kerja terhadap kinerja pegawai negeri sipil di Kantor Distrik Bahodopi, Kabupaten Morowali; 2) untuk menentukan dan menganalisis pengaruh kemampuan kerja terhadap kinerja pegawai negeri sipil; 3) untuk menentukan dan menganalisis pengaruh pengalaman kerja terhadap kinerja pegawai negeri sipil; 4) untuk menentukan dan menganalisis pengaruh disiplin kerja terhadap kinerja pegawai negeri sipil. Jenis penelitian ini adalah eksplanatif yang menunjukkan hubungan kausalitas antara variabel independen dan dependen, dan terdiri dari 30 responden yang dipilih melalui metode sensus. Berdasarkan uji analisis regresi linier berganda, penelitian ini menyimpulkan bahwa: 1) kemampuan kerja, pengalaman kerja, dan disiplin kerja secara simultan mempengaruhi kinerja pegawai negeri sipil di kantor distrik Bahodopi, Kabupaten Morowali; 2) kemampuan kerja secara signifikan dan positif mempengaruhi kinerja pegawai negeri sipil; 3) pengalaman kerja secara signifikan dan positif mempengaruhi kinerja pegawai negeri sipil; 4) disiplin kerja secara signifikan dan positif mempengaruhi kinerja pegawai negeri sipil.

3. Bachtiar Anas. 2014. Pengaruh Motivasi Terhadap Semangat Kerja Karyawan Pada PT. Federal International Finance Cabang Madiun. Alat analisis yang digunakan dalam penelitian ini adalah regresi linier berganda dengan uji $t$ dan uji $F$. Hasil analisis determinasi menunjukkan bahwa $56,0 \%$ variabel semangat kerja akan dipengaruhi oleh variabel bebasnya, yaitu Kebutuhan fisiologis (X1), Kebutuhan keamanan (X2), Kebutuhan social (X3), Kebutuhan penghargaan (X4), Kebutuhan aktualisasi diri (X5). Sedangkan sisanya $44,0 \%$ variabel semangat kerja akan dipengaruhi oleh variabel-variabel yang lain yang tidak dibahas dalam penelitian ini. Hasil analisis uji $\mathrm{t}$ (parsial) 
menunjukkan bahwa semua variabel motivasi yaitu Kebutuhan fisiologis (X1), Kebutuhan keamanan (X2), Kebutuhan social (X3), Kebutuhan penghargaan (X4), Kebutuhan aktualisasi diri (X5) mempunyai pengaruh yang signifikan terhadap semangat kerja hal ini ditunjukkan dengan nilai signifikansi yang lebih kecil dari 0,05. Hasil uji F (simultan) menunjukkan bahwa variabel motivasi secara serempak dan signifikan mempengaruhi semangat kerja karena nilai $\mathrm{F}$ hitung $>$ Ftabel $(12,810>2,443)$. Dari kelima variabel bebas yaitu Kebutuhan fisiologis (X1), Kebutuhan keamanan (X2), Kebutuhan sosial (X3), Kebutuhan penghargaan (X4), Kebutuhan aktualisasi diri (X5), variabel kebutuhan penghargaan mempunyai pengaruh yang dominan terhadap variable semangat kerja, karena mempunyai nilai t hitung yang paling besar dibandingkan nilai thitung variabel yang lain.

4. Muhammad Aris. 2014. Pengaruh Motivasi Terhadap Semangat Kerja Karyawan PT. Pelni Cabang Samarinda. Penelitian ini bertujuan untuk mengetahui apakah terdapat pengaruh yang positif antara Motivasi Terhadap Semangat Kerja Karyawan Pada PT. Pelni Cabang Samarinda. Populasi dalam penelitian ini adalah seluruh karyawan PT. Pelni Cabang Samarinda berjumlah sebanyak 40 (empat puluh) orang karyawan dijadikan sebagai responden penelitian atau dengan kata lain penelitian ini menggunakan metode sensus. Berdasarkan tujuan penelitian tersebut di atas, maka analisis data yang digunakan dalam penelitian ini adalah Koefisien Korelasi Product Moment (Pearson). Hasil analisis menunjukkan adanya Pengaruh yang Positif antara Motivasi Terhadap Semangat karyawan PT. Pelni Cabang Samarinda. Hal ini didasarkan pada hasil perhitungan yang menyatakan bahwa $r$ hitung lebih besar dari $r$ tabel yaitu 0,688 $>0,312$. Untuk nilai kritis pada $n=40$ dengan taraf signifikansi $=0.05$ dengan demikian maka kedua variabel mempunyai hubungan yang positif.
Setelah $r$ hitung didapat, maka selanjutnya penulis mengadakan pengujian dengan menggunakan uji-t. hipotesis ini, nilai $t$ hitung lebih besar dari nilai $t$ tabel dengan taraf signifikasi 0,05 untuk $\mathrm{n}-2=38$, yaitu 5,849 > atau dengan kata lain bahwa Motivasi berpengaruh positif terhadap Semangat Kerja Karyawan Pada PT. Pelni Cabang Samarinda

\section{METODE PENELITIAN}

Rancangan penelitian ini menggunakan metode kuantitatif dengan penelitian survey. Menurut Sugiyono (2015 : 13) Metode kuantitatif adalah : "Metode kuantitatif dapat diartikan sebagai metode penelitian yang berlandaskan pada filsafat positivisme, digunakan untuk meneliti pada populasi atau sampel tertentu, pengumpulan data menggunakan instrumen penelitian, analisis data bersifat kuantitaif/statistik, dengan tujuan untuk menguji hipotesis yang ditetapakan."

Sedangkan penelitian survey yaitu penelitian yang digunakan untuk menjelaskan hubungan kausal dan pengujian hipotesis. Menurut Sugiyono (2015:14) pengertian penelitian survey sebagai berikut: "Penelitian survey adalah penelitian yang dilakukan pada populasi besar maupun kecil, tetapi data yang dipelajari adalah data dari sampel yang diambil dari populasi tersebut, sehingga ditemukan kejadian-kejadian relatif, distribusi, dan hubungan-hubungan antar variabel sosiologis maupun psikologis."

Dalam penelitian survey ini, penulis melakukan penelitian pada Badan Kepegawaian dan Pengembangan Sumber Daya Manusia Kabupaten Barito Selatan dan pada para pegawai negeri sipil Kabupaten Barito Selatan di Buntok yang aktif untuk memperoleh data yang berhubungan dengan penelitian ini. Data yang diperoleh akan dianalisis menggunakan uji statistik agar ditemukan fakta dari masing-masing variabel yang diteliti serta diketahui pengaruhnya antara variabel bebas dengan variabel terikat.

Identifikasi variabel yang digunakan dalam penelitian ini yaitu :

a. Variabel Bebas (Independen Variable): 
$\mathrm{X}_{1}=$ Motivasi

$\mathrm{X}_{2}=$ Kompetensi

b. Variabel Terikat (Dependent Variabel):

$\mathrm{Y}=$ Kinerja pegawai negeri sipil

c. Variabel Mediasi (Intervening Variabel): $\mathrm{Z}=$ Tugas Belajar

Sumber data dalam penelitian ini diperoleh langsung dari responden dan pimpinan yang meliputi data tentang variabel bebas berupa motivasi, kompetensi, melalui tugas belajar dan tingkat kinerja pegawai negeri sipil Kabupaten Barito Selatan di Buntok.

Populasi menurut Sugiyono (2013:117), adalah wilayah generalisasi yang terdiri dari objek atau subjek yang mempunyai kualitas dan karakteristik tertentu yang ditetapkan oleh peneliti untuk dipelajari dan kemudian ditarik kesimpulannya. Populasi dalam penelitian ini adalah semua Pegawai Negeri Sipil di Kabupaten Barito Selatan yang di khususkan kepada Pegawai Negeri Sipil yang sudah selesai menjalani Tugas Belajar maupun Pegawai Negeri Sipil yang sedang menjalani Tugas Belajar dengan pembiayaan melalui APBD Kabupaten Barito Selatan. Jumlah populasi Pegawai Negeri Sipil Kabupaten Barito Selatan di Buntok yang menjadi responden berjumlah 71 orang pegawai.

Pengertian sampel menurut Sugiyono (2012:73) adalah bagian dari jumlah dan karakteristik yang dimiliki oleh populasi tersebut sampel yang diambil dari populasi tersebut harus betul-betul representative (mewakili). Ukuran sampel merupakan banyaknya sampel yang akan diambil dari suatu populasi. Menurut Arikunto (2012:104) jika jumlah populasinya kurang dari 100 orang, maka jumlah sampelnya diambil secara keseluruhan, tetapi jika populasinya lebih besar dari 100 orang, maka bisa diambil $10-15 \%$ atau 20-25\% dari jumlah populasinya. Berdasarkan penelitian ini karena jumlah populasinya tidak lebih besar dari 100 orang responden, maka penulis mengambil $100 \%$ jumlah populasi Pegawai Negeri Sipil yang sudah selesai menjalani Tugas Belajar maupun Pegawai Negeri Sipil yang sedang menjalani Tugas Belajar dengan pembiayaan melalui APBD Kabupaten
Barito Selatan yaitu sebanyak 71 orang responden. Dengan demikian penggunaan seluruh populasi tanpa harus menarik sampel penelitian sebagai unit observasi disebut sebagai teknik sensus.

Model penelitian yang digunakan dalam penelitian ini yaitu analisis kuantitatif berupa analisis jalur (path analysis) menggunakan analisis regresi linier berganda, dengan bantuan program SPSS Statistics versi 21.0. Pengukuran untuk masing - masing variabel menggunakan skala likert. Skala likert adalah skala berjenjang yang di gunakan untuk mengukur sikap, pendapat dan persepsi seseorang atau sekelompok kejadian (Riduwan, 2012: 68).

Analisis Linear Berganda adalah untuk melihat apakah ada pengaruh secara linear antara dua atau lebih variabel independen terhadap variabel dependen (Priyanto 2010:61). Analisis ini untuk memperediksi nilai dari variabel dependen apabila nilai variabel independen mengalami kenaikan atau penurunan dan untuk mengetahui arah pengaruh antara pengaruh variabel independen dan variabel dependen. Apakah masing-masing variabel independen berpengaruh positif atau negatif.

\section{HASIL PENELITIAN DAN PEMBAHASAN \\ Analisis Jalur I dan II}

Nilai-nilai koefisien regresi linier berganda (multiple linear regression analysis) dari persamaan 1 yang menghubungkan antara Motivasi, kompetensi terhadap Tugas Belajar; maupun persamaan 2 yang menghubungkan antara Motivasi, kompetensi, dan Tugas Belajar terhadap Kinerja Pegawai Negeri Sipil Kabupaten Barito Selatan di Buntok tercermin dalam gambar dan tabel berikut ini : 


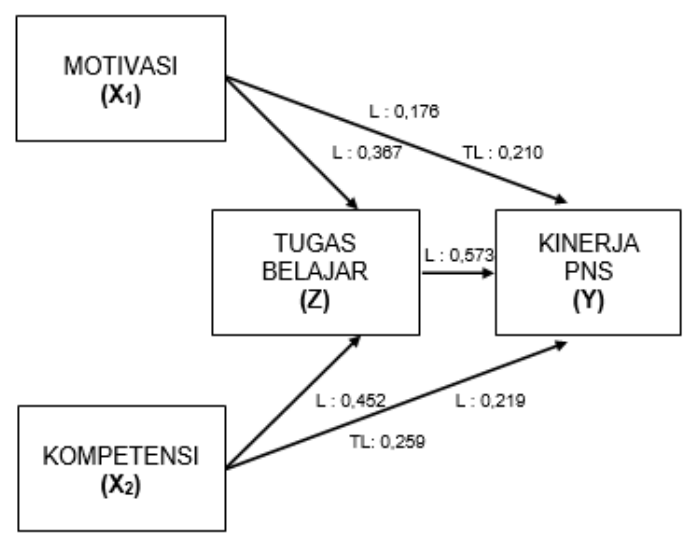

Gambar 1 Analisis Jalur

\section{Keterangan :}

L : Pengaruh Langsung

TL : Pengaruh Tidak

Langsung

Pengaruh Tidak Langsung $\mathrm{X}_{1} \rightarrow \mathrm{Y}$

$=0,367 \times 0,573$

$=0,210>$ Pengaruh Langsung 0,176

Pengaruh Tidak Langsung $\mathrm{X}_{2} \rightarrow \mathrm{Y}$

$=0,452 \times 0,573$

$=0,259>$ Pengaruh Langsung 0,219

Tabel 1 Koefisien Regresi Model I dan Model II

\begin{tabular}{|cccccc|}
\hline $\begin{array}{c}\text { Mod } \\
\text { el }\end{array}$ & el & $\begin{array}{c}\text { Unstanda } \\
\text { rdised } \\
\text { Coefficie } \\
\text { nt B }\end{array}$ & $\begin{array}{c}\text { Standar } \\
\text { dized } \\
\text { Coeffici } \\
\text { ent } \\
\text { Beta }\end{array}$ & t & sig \\
\hline 1 & (Const & 0,066 & & 0, & 0 \\
& ant) & & & 16 & 86 \\
& & & & 8 \\
\hline & Motiva & 0,493 & 0,444 & 4, & 0, \\
si & & & 36 & 00 \\
& & & & 1 & 0 \\
\hline & Kompe & 0,497 & 0,427 & 4, & 0, \\
& tensi & & & 19 & 00 \\
& & & 5 & 0 \\
\hline 2 & (Const & $-0,645$ & & - & 0, \\
& ant) & & & 2, & 01 \\
& & & 45 & 7 \\
& & & 3 & \\
\hline Motiva & 0,293 & 0,235 & 3, & 0, \\
si & & & 39 & 00 \\
& & & 1 & 1 \\
\hline
\end{tabular}

\begin{tabular}{|llccc|}
\hline Kompe & 0,229 & 0,176 & 2, & 0, \\
tensi & & & 55 & 01 \\
& & & 3 & 3 \\
\hline Tugas & 0,695 & 0,619 & 7, & 0, \\
belajar & & & 91 & 00 \\
& & & 3 & 0 \\
\hline
\end{tabular}

a. Dependent variable model 1 : Tugas Belajar

b. Dependent variable model 2 : Kinerja Pegawai Negeri Sipil

Berdasarkan tabel di atas diketahui persamaan empiris regresi Model I dalam penelitian ini sebagai berikut :

$$
\mathrm{Z}=0,066+0,493 \mathrm{X}_{1}+0,497 \mathrm{X}_{2}+\mathrm{E}
$$

Dimana :

$$
\begin{aligned}
& \mathbf{Z}=\text { Tugas Belajar } \\
& \mathbf{X}_{\mathbf{1}}=\text { Motivasi } \\
& \mathbf{X}_{\mathbf{2}}=\text { Kompetensi }
\end{aligned}
$$

Persamaan regresi empiris model I tersebut mengindikasikan hal-hal sebagai berikut :

a. Nilai koefisien regresi Motivasi $X_{1}$ sebesar 0,493 menunjukkan terdapat pengaruh positif Motivasi terhadap Tugas belajar. Jika skor variabel Motivasi meningkat satu satuan maka Tugas belajar akan meningkat sebesar 0,493 satuan dengan asumsi variabel lain konstan. Sebaliknya jika skor variabel Motivasi turun satu satuan maka Tugas belajar akan turun sebesar 0,493 satuan dengan asumsi variabel lain konstan. Hal ini berarti semakin baik Motivasi, maka Tugas Belajar juga semakin baik.

b. Nilai koefisien regresi Kompetensi $\mathrm{X}_{2}$ sebesar 0,497 menunjukkan terdapat pengaruh positif kompetensi terhadap Tugas belajar. Jika skor kompetensi meningkat satu satuan maka Tugas belajar akan meningkat sebesar 0,497 satuan dengan asumsi variabel lain konstan. Sebaliknya jika skor kompetensi turun satu satuan maka Tugas belajar akan turun sebesar 0,497 satuan dengan asumsi variabel lain konstan. Hal ini berarti semakin baik Kompetensi, maka Tugas Belajar juga semakin baik

Dari hasil output SPSS Model I tersebut dapat diketahui bahwa nilai 
koefisien beta variabel Motivasi adalah sebesar 0,444 berarti Motivasi mempunyai kontribusi terhadap perubahan Tugas Belajar sebesar 44,4\%. Nilai koefisien beta Kompetensi adalah sebesar 0,427 berarti kompetensi mempunyai kontribusi terhadap perubahan Tugas belajar sebesar $42,7 \%$. Karena pengaruh parsial variabel Motivasi sebesar 44,4\% lebih tinggi dari variabel Kompetensi maka variabel Motivasi mempunyai pengaruh dominan terhadap Tugas Belajar.

Berdasarkan tabel di atas dapat disajikan ke dalam formulasi model empiris dalam Model II dalam penelitian ini sebagai berikut :

$$
\begin{gathered}
Y=-0,645+0,293 X_{1}+0,229 X_{2}+0,695 Z \\
+E
\end{gathered}
$$

Dimana :

$$
\begin{aligned}
& \mathbf{Z}=\text { Tugas Belajar } \\
& \mathbf{X}_{\mathbf{1}}=\text { Motivasi } \\
& \mathbf{X}_{\mathbf{2}}=\text { Kompetensi } \\
& \mathbf{Y}=\text { Kinerja Pegawai Negeri Sipil }
\end{aligned}
$$

Persamaan regresi empiris model II tersebut mengindikasikan hal-hal sebagai berikut :

a. Nilai koefisien regresi Motivasi $X_{1}$ sebesar 0,293 menunjukkan terdapat pengaruh positif Motivasi terhadap Kinerja Pegawai Negeri Sipil. Jika skor variabel Motivasi meningkat satu satuan maka Kinerja pegawai negeri sipil akan meningkat sebesar 0,293 satuan dengan asumsi variabel lain konstan. Sebaliknya jika skor variabel Motivasi turun satu satuan maka Kinerja Pegawai Negeri Sipil akan turun sebesar 0,293 satuan dengan asumsi variabel lain konstan. Hal ini berarti semakin baik Motivasi, maka Kinerja Pegawai Negeri Sipil juga semakin baik.

b. Nilai koefisien regresi Kompetesi $\mathrm{X}_{2}$ sebesar 0,229 menunjukkan terdapat pengaruh positif kompetensi terhadap Kinerja pegawai negeri sipil. Jika skor kompetensi meningkat satu satuan maka Kinerja Pegawai Negeri Sipil akan meningkat sebesar 0,229 satuan dengan asumsi variabel lain konstan. Sebaliknya jika skor kompetensi turun satu satuan maka Kinerja Pegawai Negeri Sipil akan turun sebesar 0,229 satuan dengan asumsi variabel lain konstan. Hal ini berarti semakin baik Kompetensi, maka Kinerja Pegawai Negeri Sipil juga semakin baik.

c. Nilai koefisien regresi Tugas Belajar Z sebesar 0,695 menunjukkan terdapat pengaruh positif Tugas Belajar terhadap Kinerja Pegawai Negeri Sipil. Jika skor Tugas Belajar meningkat satu satuan maka Kinerja Pegawai Negeri Sipil akan meningkat sebesar 0,695 satuan dengan asumsi variabel lain konstan. Sebaliknya jika skor Tugas Belajar turun satu satuan maka Kinerja Pegawai Negeri Sipil akan turun sebesar 0,695 satuan dengan asumsi variabel lain konstan. Hal ini berarti semakin baik Tugas Belajar, maka Kinerja Pegawai Negeri Sipil juga semakin baik.

Dalam Model II tersebut dapat diketahui bahwa nilai koefisien beta variabel Motivasi adalah sebesar 0,235 berarti Motivasi mempunyai kontribusi terhadap perubahan Kinerja Pegawai Negeri Sipil sebesar 23,5\%. Nilai koefisien beta Kompetensi adalah sebesar 0,176 berarti Kompetensi mempunyai kontribusi terhadap perubahan Kinerja Pegawai Negeri Sipil sebesar $17,6 \%$. Nilai koefisien beta Tugas Belajar adalah sebesar 0,619 berarti Tugas Belajar mempunyai kontribusi terhadap perubahan Kinerja Pegawai Negeri Sipil sebesar $61,9 \%$. Karena pengaruh parsial variabel Tugas Belajar sebesar 61,9\% lebih tinggi dari variabel lain maka variabel Tugas Belajar mempunyai pengaruh dominan terhadap Kinerja Pegawai Negeri Sipil.

\section{Analisis Regresi (Model Fit Persamaan Regresi)}

Persamaan regresi memiliki model fit jika koefisien Adjusted $R$ Squared mendekati nilai 1. Nilai Adjusted $R$ Squared dalam Model Summary dapat ditunjukkan pada table berikut ini : 
Tabel 2 Model Summary Model I dan Model II

\begin{tabular}{|ccccc|}
\hline $\begin{array}{c}\text { Mod } \\
\text { el }\end{array}$ & $\mathbf{R}$ & $\begin{array}{c}\mathbf{R} \\
\text { Squar } \\
\mathbf{e}\end{array}$ & $\begin{array}{c}\text { Adjuste } \\
\mathbf{d} \\
\mathbf{R} \\
\text { Square }\end{array}$ & $\begin{array}{c}\text { Std. } \\
\text { Error } \\
\text { of the } \\
\text { Estimat } \\
\mathbf{e}\end{array}$ \\
\hline 1 & $\begin{array}{c}0,76 \\
5\end{array}$ & 0,586 & 0,571 & 0,42806 \\
\hline 2 & $\begin{array}{c}0,92 \\
6\end{array}$ & 0,858 & 0,850 & 0,28378 \\
\hline
\end{tabular}

a. Model 1 Predictors : (Constant), Motivasi, Kompetensi

b. Model 2 Predictors : (Constant), Motivasi, Kompetensi, Tugas Belajar

Dari model summary model I tersebut di atas, nilai Adjusted $R$ Squared $=0,571$ berarti sebesar $57,1 \%$ perubahan dari Tugas Belajar dapat dijelaskan secara bersamasama oleh variabel Motivasi dan Kompetensi di dalam model I, sedangkan sisanya $42,9 \%$ dijelaskan oleh variabel lain di luar model I.

Dari model summary model II tersebut di atas, nilai Adjusted $R$ Squared $=0,850$ berarti sebesar $85,0 \%$ perubahan dari Kinerja Pegawai Negeri Sipil dapat dijelaskan secara bersama-sama oleh variabel Motivasi, Kompetensi dan Tugas Belajar di dalam model II, sedangkan sisanya $15,0 \%$ dijelaskan oleh variabel lain di luar model II.

Dari kedua persamaan regresi baik pada model I (pengaruh Motivasi dan Kompetensi terhadap Tugas Belajar) maupun model II (pengaruh Motivasi, Kompetensi dan Tugas Belajar terhadap Kinerja Pegawai Negeri Sipil), masing-masing menunjukkan adanya model fit.

\section{Hasil Uji Hipotesis}

Pengujian hipotesis secara parsial dari persamaan regresi Model I dan Model II, pengaruh Motivasi dan Kompetensi terhadap Kinerja Pegawai Negeri Sipil melalui Tugas Belajar disajikan sebagai berikut :

\section{H1 Motivasi Berpengaruh Secara Langsung Terhadap Tugas Belajar Pegawai Negeri Sipil Kabupaten Barito Selatan di Buntok.}

Dari Tabel diatas diperoleh bahwa beta standardized coefficient sebesar 0,444 bertanda positif dan nilai thitung sebesar 4,361 lebih besar dari $t_{\text {tabel }}$ sebesar 1,671 $(\mathrm{DF}=71-3-1=67)$, maka dengan demikian terbukti bahwa hipotesis diterima, artinya Motivasi berpengaruh positif dan signifikan terhadap Kinerja Pegawai Negeri Sipil Kabupaten Barito Selatan di Buntok.

$\mathrm{H}_{2}$ Kompetensi Berpengaruh Secara Langsung Terhadap Tugas Belajar Pegawai Negeri Sipil Kabupaten Barito Selatan di Buntok.

Dari Tabel diatas diperoleh nilai beta standardized coefficient 0,427 dan bertanda positif dan thitung 4,195 dan lebih besar dari $t_{\text {tabel }} 1,671$ maka dengan demikian terbukti bahwa hipotesis diterima, artinya Kompetensi berpengaruh positif dan signifikan terhadap Tugas Belajar Pegawai Negeri Sipil Kabupaten Barito Selatan di Buntok.

H3 Motivasi Berpengaruh Secara Langsung Terhadap Kinerja Pegawai Negeri Sipil Kabupaten Barito Selatan di Buntok.

Dari Tabel diatas diperoleh bahwa beta standardized coefficient sebesar 0,235 bertanda positif dan nilai $t_{\text {hitung }}$ sebesar 3,391 lebih besar dari $t_{\text {tabel }}$ sebesar 1,671 $(\mathrm{DF}=71-3-1=67)$, maka dengan demikian terbukti bahwa hipotesis diterima, artinya Motivasi berpengaruh positif dan signifikan terhadap Kinerja Pegawai Negeri Sipil Kabupaten Barito Selatan di Buntok.

$\mathrm{H}_{4}$ Kompetensi Berpengaruh Secara Langsung Terhadap Kinerja Pegawai Negeri Sipil Kabupaten Barito Selatan di Buntok.

Dari Tabel diatas diperoleh bahwa beta standardized coefficient sebesar 0,176 bertanda positif dan nilai $t_{\text {hitung }}$ sebesar 2,553 lebih besar dari $t_{\text {tabel }}$ sebesar 1,671 $(\mathrm{DF}=71-3-1=67)$, maka dengan demikian terbukti bahwa hipotesis diterima, artinya Kompetensi berpengaruh positif dan signifikan 
terhadap Kinerja Pegawai Negeri Sipil Kabupaten Barito Selatan di Buntok.

H5 Tugas belajar Berpengaruh Secara Langsung Terhadap Kinerja Pegawai Negeri Sipil Kabupaten Barito Selatan di Buntok.

Dari Tabel diatas diperoleh bahwa beta standardized coefficient sebesar 0,619 bertanda positif dan nilai $t_{\text {hitung }}$ sebesar 7,913 lebih besar dari tabel sebesar 1,671 $(\mathrm{DF}=71-3-1=67)$, maka dengan demikian terbukti bahwa hipotesis diterima, artinya Tugas Belajar berpengaruh positif dan signifikan terhadap Kinerja pegawai negeri sipil di Kabupaten Barito Selatan.

\section{Pembahasan}

1. Pengaruh Motivasi Secara Langsung Terhadap Tugas Belajar Pegawai Negeri Sipil Kabupaten Barito Selatan di Buntok.

Hasil uji hipotesis 1 dihasilkan bahwa Motivasi secara langsung berpengaruh positif dan signifikan terhadap Tugas Belajar Pegawai Negeri Sipil Kabupaten Barito Selatan di Buntok. Hal ini dibuktikan dengan beta standardized coefficient sebesar 0,444 yang artinya bahwa meningkatnya Motivasi akan diikuti oleh meningkatnya Kinerja Pegawai Negeri Sipil Kabupaten Barito Selatan di Buntok. Pengaruh positif dan signifikan terbukti dari nilai $t_{\text {hitung }}$ sebesar 4,361 lebih besar dari tabel sebesar 1,671.

Motivasi yang diterapkan di lingkungan pemerintah khususnya di Kabupaten Barito Selatan secara langsung berpegaruh terhadap minat Tugas Belajar yang diprogramkan oleh Pemerintah Daerah. Peran kepemimpinan di Kabupaten Barito Selatan yang memprioritaskan prinsip motivasi akan mendorong para Pegawai Negeri Sipil untuk mengikuti apa yang dilakukan pimpinannya baik terpaksa atau tidak namun secara sistemis akan mengubah perilaku Pegawai Negeri Sipil yang lebih giat dalam bekerja atau dengan kata lain meningkatkan kemampuannya melalui Tugas Belajar. Hasil penelitian ini didukung oleh penelitian sebelumnya yaitu oleh Nattee Kachornkittiya, Charlee Trichan, Sanguan Lerkiatbundit (2012), dimana Motivasi ditemukan memiliki korelasi positif dengan Tugas Belajar dalam penelitian ini. Demikian juga, Ritz (2009) menemukan bahwa Motivasi memiliki korelasi positif dengan ketertarikan dalam pembuatan kebijakan publik dan komitmen untuk kepentingan umum. Dengan adanya Motivasi yang berkorelasi positif terhadap Tugas Belajar, maka selanjutnya akan meningkatkan Kinerja Pegawai Negeri Sipil untuk lebih baik lagi.

2. Pengaruh Kompetensi Secara Langsung Terhadap Tugas Belajar Pegawai Negeri Sipil Kabupaten Barito Selatan di Buntok.

Hasil pengujian hipotesis

Kompetensi berpengaruh secara langsung terhadap Tugas Belajar Pegawai Negeri Sipil Kabupaten Barito Selatan di Buntok. Hal ini dibuktikan dengan beta standardized coefficient sebesar 0,427 yang artinya bahwa meningkatnya Kompetensi akan diikuti oleh meningkatnya minat untuk mengikuti program Tugas Belajar Pegawai Negeri Sipil Kabupaten Barito Selatan di Buntok. Pengaruh positif dan signifikan terbukti dari nilai thitung sebesar 4,195 lebih besar dari tabel sebesar 1,671.

3. Pengaruh Motivasi Secara Langsung Terhadap Kinerja Pegawai Negeri Sipil Kabupaten Barito Selatan di Buntok.

Hasil pengujian
menyimpulkan bahwa $\begin{array}{r}\text { Motivasi } \\ \text { berpengaruh positif dan signifikan } \\ \text { terhadap Kinerja Pegawai Negeri Sipil } \\ \text { Kabupaten Barito Selatan di Buntok. Hal } \\ \text { ini dapat dibuktikan dari hasil beta }\end{array}$


standardized coefficient sebesar 0,235 bertanda positif dan nilai $t_{\text {hitung }}$ sebesar 3,391 lebih besar dari tabel sebesar 1,671 $(\mathrm{DF}=71-3-1=67)$.

Hasil penelitian ini mendukung hasil penelitian sebelumnya oleh Suhadi Prayitno (2017), di RSI Siti Aisyah Madiun dimana hasil penelitiannya menunjukkan terdapat pengaruh pemahaman Motivasi terhadap kinerja perawat, RSI Siti Aisyah Madiun. Pimpinan menginternalisasi motivasi kepada seluruh anggota RSI Siti Aisyah Madiun.

Oleh karena itu Motivasi perlu lebih didorong secara berkelanjutan di lingkungan Pemerintah Kabupaten Barito Selatan sehingga para Pegawai Negeri Sipil lebih termotivasi, lebih mengenal semangat satu sama lain, lebih mengenal daya juang dari lingkungan organisasi sehingga menunjang layanan publik sebagai bagian dari Kinerja Pegawai Negeri Sipil dari para Pegawai Negeri Sipil Kabupaten Barito Selatan di Buntok.

4. Pengaruh Kompetensi Secara Langsung Terhadap Kinerja Pegawai Negeri Sipil Kabupaten Barito Selatan di Buntok.

Hasil pengujian hipotesis Kompetensi berpengaruh secara langsung terhadap Kinerja Pegawai Negeri Sipil Kabupaten Barito Selatan di Buntok. Hal ini dibuktikan dengan beta standardized coefficient sebesar 0,176 yang artinya bahwa meningkatnya Kompetensi akan diikuti oleh meningkatnya minat untuk mengikuti program Tugas Belajar Pegawai Negeri Sipil Kabupaten Barito Selatan di Buntok. Pengaruh positif dan signifikan terbukti dari nilai $t_{\text {hitung }}$ sebesar 2,553 lebih besar dari $t_{\text {tabel }}$ sebesar 1,671.

5. Pengaruh Tugas Belajar Secara Langsung Terhadap Kinerja Pegawai Negeri Sipil Kabupaten Barito Selatan di Buntok.

Hasil pengujian menunjukkan bahwa Tugas Belajar mempunyai pengaruh langsung terhadap Kinerja
Pegawai Negeri Sipil Kabupaten Barito Selatan di Buntok. Hal ini dibuktikan dengan beta standardized coefficient sebesar 0,619 yang artinya bahwa meningkatnya Kompetensi akan diikuti oleh meningkatnya minat untuk mengikuti program Tugas Belajar Pegawai Negeri Sipil Kabupaten Barito Selatan di Buntok. Pengaruh positif dan signifikan terbukti dari nilai thitung sebesar 7,913 lebih besar dari tabel sebesar 1,671.

Temuan ini memberikan implikasi bahwa upaya peningkatan Kinerja Pegawai Negeri Sipil menjadi lebih efektif dengan melalui peningkatan Kompetensi dengan Tugas Belajar Pegawai Negeri Sipil Kabupaten Barito Selatan di Buntok.

\section{KESIMPULAN}

Sesuai dengan hasil penelitian tersebut dapat disimpulkan beberapa hal diantaranya sebagai berikut :

$\mathrm{H}_{1}$ Motivasi $\left(\mathrm{X}_{1}\right)$ berpengaruh positif dan signifikan secara langsung terhadap Tugas Belajar (Z) Pegawai Negeri Sipil Kabupaten Barito Selatan di Buntok.

$\mathrm{H}_{2}$ Kompetensi $\left(\mathrm{X}_{2}\right)$ berpengaruh positif dan signifikan secara langsung terhadap Tugas Belajar (Z) Pegawai Negeri Sipil Kabupaten Barito Selatan di Buntok.

$\mathrm{H}_{3}$ Motivasi $\left(\mathrm{X}_{1}\right)$ berpengaruh positif dan signifikan secara langsung terhadap Kinerja Pegawai Negeri Sipil (Y) Kabupaten Barito Selatan di Buntok.

$\mathrm{H}_{4}$ Kompetensi $\left(\mathrm{X}_{2}\right)$ berpengaruh positif dan signifikan secara langsung terhadap Kinerja Pegawai Negeri Sipil (Y) Kabupaten Barito Selatan di Buntok.

$\mathrm{H}_{5}$ Tugas Belajar (Z) berpengaruh positif terhadap Kinerja Pegawai Negeri Sipil (Y) Kabupaten Barito Selatan di Buntok.

\section{SARAN}

Sebagai masukkan maka dapat diberikan sumbang saran yang dapat diajukan bagi perbaikan Kinerja Pegawai Negeri Sipil dan layanan publik Pemerintah Daerah Kabupaten Barito Selatan di Buntok 
yang merupakan implikasi dari hasil penelitian antara lain :

1. Guna meningkatkan Kinerja Pegawai Negeri Sipil dalam layanan publik yang lebih baik, maka variabel yang terdiri dari Motivasi, Kompetensi, Tugas Belajar perlu ditingkatkan secara berkesinambungan sehingga Kinerja Pegawai Negeri Sipil Kabupaten Barito Selatan di Buntok lebih meningkat di masa yang akan datang.

2. Pihak manajemen di lingkungan Pemerintah Kabupaten Barito Selatan di Buntok perlu memberikan perhatian khusus dalam hal Tugas Belajar sebagai skala prioritas dalam meningkatkan Kinerja Pegawai Negeri Sipil Kabupaten Barito Selatan di Buntok dengan upaya keras melalui Tugas Belajar dengan skala prioritas sehingga menunjang layanan publik penuh empati yang mengerti akan kebutuhan masyarakat luas.

3. Peran kepemimpinan di lingkungan Pemerintah Kabupaten Barito Selatan di Buntok yang memprioritaskan Motivasi perlu ditingkatkan sehingga mampu mendorong para Pegawai Negeri Sipil untuk mengikuti apa yang dilakukan pimpinannya baik terpaksa atau tidak namun secara sistemis akan mengubah perilaku Pegawai Negeri Sipil yang lebih giat dalam bekerja atau dengan kata lain meningkatkan Kinerja Pegawai Negeri Sipil Kabupaten Barito Selatan di Buntok.

4. Kompetensi perlu lebih dikembangkan di lingkungan Pemeritah Daerah Kabupaten Barito Selatan di Buntok sehingga para Pegawai Negeri Sipil lebih berkompeten, lebih mengenal kebutuhan masyarakat serta lebih mengenal lingkungan masyarakat sehingga menunjang layanan publik sebagai bagian dari Kinerja Pegawai Negeri Sipil Kabupaten Barito Selatan di Buntok

DAFTAR PUSTAKA

Abdul Rachman, Arifin. 2006. Administrasi Pemerintahan Dalam Pembangunan,. CV. Haji Mas Agung. Jakarta.
Bohlander, George., and Snell, Scott. 2010. Principles of Human Resource. Management, 15th ed. Mason, OH: South Western - Cengage Learning.

Byars, Lloyd. L. And Rue, Leslie. W., 2004, 6 th ed, Human Resource Management, The. Mc Graw-Hill, North America.

Casio, Wayne F. 2002. Managing Human Resources: $\quad$ Productivity, Quality of Work Life, Profit. Singapore: McGraw-Hill International Editors.

Daft L, Richard. 2003. Manajemen. Jakarta : Erlangga.

Donnely, Gibson Ivancevich. 2005. Organisasi Perilaku, Struktur, Proses, Erlangga, Jakarta.

Follet, Mary Parker. 2007. Manajemen. Jakarta: Indeks

Gerson, R. F. 2001. Mengukur Kepuasan Pelanggan, Seri Panduan Praktis No. 17. Jakarta: PPM.

Ghozali, Iman, 2002, Aplikasi Analisis Multivariate dengan Program SPSS. Badan Penerbit Universitas Diponegoro. Semarang.

Gujarati, Damodar, 2001, Ekonometrika Dasar alih bahasa Sumarno zain, Penerbit Eerlangga, Jakarta

Hamzah. B. Uno. 2012. Profesi Kependidikan. Jakarta. Bumi Aksara

Handoko, T. Hani 2008, Manajemen Personalia Dan Sumber Daya Manusia, Penerbit BPFE Yogyakarta

Hasibuan, M. S. P. 2010. Manajemen Sumber Daya Manusia. Jakarta: Bumi Aksara.

Lewis, 2004, Kinerja Organisasi : Yogyakarta : UGM.

Mangkunegara, Anwar Prabu. 2011. Sumber Daya Manusia Perusahaan. Bandung: PT Remaja Rusdakarya.

McGregor, Douglas, The Human Side of 
Enterprise, Mc.Graw-Hill Book Company, New York, 2000.

Miles, Mattew B dan Huberman. A Michel. 2005. Analisis Data Kualitatif: Buku Sumber Tentang Metode - Metode Baru. Terj. Tjetjep Rohindi Rohidi. UI Press: Jakarta

Moeheriono. 2012. Pengukuran Kinerja Berbasis Kompetensi. Jakarta : PT. Rajagrafindo Persada.

Nickel W., McHugh \& McHugh. 2003, Understanding Business, Irwin,. London.

Noe, Raymond A., John R. Hollenbeck, Barry Gerhart, and Patrick M. Whight. 2002. Human Resource Management: Gaining a competitive advantage. Fourth Edition. USA: McGraw-Hill.

Plunket, et.al. 2005. Management : Meeting and Exceding Customer Expectations. USA : Thomson South - Western.

Prihadi, Syaiful F., 2005. Assessment Centre $\therefore$ Identifikasi, Pengukuran Dan Pengembangan Kompetensi.

Jakarta: Gramedia Pustaka Utama.

Riduan, Drs. 2012. Skala Pengukuran Variabel-variabel Penelitian. Jakarta: Alfabeta

Rivai, 2005, Manajemen Sumber daya manusia Untuk Perusahaan, Raja Garindo Perkasa

Robbins, S. P., \& Judge, T. A. 2006. Perilaku Organisasi (Organizational Behavior). Jakarta: Salemba Empat.

Robbins, Stephen dan P. Mary Coulter, Management, Prentice Hall Inc., New Jersey, 2009.

Rosyidi, Bahrur. 2020. Manajemen Pembaharuan.

https://www.slideshare.net/ bahrurrosyididuraisy/manaje men-pembaharuan. diakses 25 Januari 2020
Ruvendi, Ramlan, 2005, Imbalan dan Gaya Kepemimpinan Pengaruhnya Terhadap Kepuasan Kerja Karyawan di Balai Besar Industri Hasil Pertanian Bogor. Jurnal Imiah Binaniaga. Vo. 1. No. 1. hal. 17-26.

Sarlito, Wirawan Sarwono. 2011. Psikologi Remaja. Jakarta: Raja Grafindo Persada.

Sedarmayanti, 2001 Sumber daya manusia Dan Produktivitas Kerja, Edisi Pertama, Cetakan Kedua Penerbit mandar Maju

Siagian, Sondang P 2003, Manajemen Sumber Daya Manusia, Edisi Pertama, Cetakan Kesepuluh, Penerbit Bumi Aksara

Siagian, Sondang P, 2008, Peranan Staf dalam Manajemen, Gunung Agung, Jakarta

Sikula, Andrew

F. 2001. Manajemen Sumber Daya

Manusia. Erlangga.Bandung.

Silalahi, 2009. Asas-asas Manajemen

Modern, Liberty, Yogyakarta.

Simamora, H. (2004). Manajemen Sumber Daya Manusia. Yogyakarta: STIE YKPN.

Singarimbun, Masri dan Sofyan Efendi, 2005, Metode Penelitian Survey, LP3ES,. Jakarta.

Soeprihanto, Jhon, dkk., 2008. Perilaku Organisasional. Yogyakarta: Sekolah Tinggi Ilmu Ekonomi YKPN.

Sofyandi,

Herman.

2013. Manajemen Sumber

Daya Manusia,. Yogyakarta: Graha ilmu

Spencer dan Spencer, 2008, Competence At Work. John Wiley \& Son. Canada

Steiner, G.A. 2006. Bussiness, Goverment and Society: a Managerial perspective ed. 10. Mc-Graw Hill, New York

Stolovitch and Keeps, 2002. Handbook of Human Performance 
Technology A Comprehensive

Guide for Analysis and Solving Performance Problem in Organizations. San Francisco: Jersey.

Stoner, James A.F. 2006, Manajemen, Terjemahan : Antarikso, dkk, Erlangga, Jakarta.

Sudarmanto, 2009. Kinerja dan Pengembangan Kompetensi SDM,. Yogyakarta : Pustaka Pelajar,

Sugiyono, 2015. Metode Penelitian Bisnis, $\mathrm{CV}$. Alfabeta, Bandung.

Supranto, MA, 2000, Teknik Sampling, untuk Survey \& Eksprimen. Jakarta : Erlangga.

Sutrisno, E. 2011. Manajemen Sumber Daya Manusia. Jakarta : Kencana Prenada Media Group

Sutrisno, Hadi. 2004. Metodologi Research. Andi Offset : Yogyakarta
Terry, George R. 2001. Azas-Azas Manajemen, Alumni, Bandung.

Wibowo. 2010. Manajemen Kinerja. Jakarta: Rajawali Press.

Wirawan. 2009. Evaluasi Kinerja Sumber Daya Manusia. Jakarta : Salemba.

Zameer, Hashim, Shehzad Ali, Waqar Nisar dan Muhammad Amir. 2014. The Impact of the Motivation on the Employee's Performance in Beverage Industry of Pakistan. International Journal of Academic Research in Accounting, Finance and Management Sciences Vol. 4, No.1. p. 293-298.

www.wikipedia.com.diakses 27 Juli 2020. www.bkn.go.id. diakses 27 Juli 2020. 